\title{
Correlations of Mechanical Stability, Morphology, Pul- monary Surfactant, and Phospholipid Content in the Developing Lamb Lung*
}

\author{
George W. Brumley, Victor Chernick, W. Alan Hodson, Colin Normand, \\ Axel Fenner, and Mary Ellen Avery $\dagger$ \\ (From the Department of Pediatrics, Johns Hopkins University School of Medicine, and the \\ Harriet Lane Service of the Children's Medical and Surgical Center of the \\ Johns Hopkins Hospital, Baltimore, Md.)
}

\begin{abstract}
Summary. Pressure-volume characteristics and surface tension measurements of the lamb of 120 to 130 days gestational age were typical of the mature lung in the upper lobes and the immature lung in the lower lobes. By term both upper and lower lobes had findings characteristic of the mature animal.

Phospholipid concentration per milligram DNA and per cent saturated fatty acids on pulmonary phosphatidyl choline were relatively constant from 60 to 120 days gestational age; thereafter there was a significant increase in both measurements. These changes usually coincided with an increase in osmiophilic inclusion bodies in the large alveolar cell.

A concentration of disaturated phosphatidyl choline per milligram DNA in excess of $0.170 \mathrm{mg}$ per $\mathrm{mg}$ was associated with a minimal surface tension below 13 dynes per $\mathrm{cm}(\mathrm{p}<0.001)$. Newborn animal lungs contained over 3 times this critical concentration, whereas adult lungs contained 1.5 times this value. The excess disaturated phosphatidyl choline per milligram DNA may represent a reservoir of pulmonary surfactant.
\end{abstract}

\section{Introduction}

The lamb lung undergoes marked anatomical, physiological, and morphological changes during development. The classic paper of Fauré-Fremiet and Dragoiu (1) in 1923 illustrated many of these changes including the high glycogen content early in gestation and the increasing water and amino nitrogen content toward term. Now, tools such as the surface tension balance (2) and the electron microscope (3) have been applied to the study of the lung. In this study morphology, pres-

* Submitted for publication July 26, 1966; accepted February 2, 1967.

This work was supported in part by U. S. Public Health Service grants HD 00281-07 and 2 F 11-NB-121202.

Presented in part, American Physiological Society, April 15, 1966, and abstracted in Fed. Proc. 1966, 25, 565.

† Address requests for reprints to Dr. Mary Ellen Avery, Johns Hopkins Hospital, Baltimore, Md. 21205. sure-volume characteristics, and phospholipid composition in the same lambs at different gestational ages further elucidate lung developmental patterns. The upper lobes were studied separately from the middle and lower lobes of all animals since it is known that in the lamb between 120 and 130 days gestational age the upper portion of the lung is more mature functionally than the lower portion (4). This fact of differential maturation provides an exceptional opportunity to correlate chemical, histologic, and functional changes.

\section{Methods}

Twenty-one pregnant ewes of mixed breed were anesthetized for cesarean section with approximately $10 \mathrm{mg}$ per $\mathrm{kg}$ pentobarbital intravenously. Blood pressure was monitored through a carotid cannula with a pressure transducer and displayed on an oscilloscope; arterial $\mathrm{pH}$ and oxygen and carbon dioxide tensions were measured with standard electrodes. Infrequently, oxygen and assisted ventilation through an endotracheal tube were 
necessary to maintain blood gas values within normal limits in some oversedated ewes.

Twenty-seven lambs including six sets of twins were delivered; the head of each was covered immediately with a saline-filled condom to prevent air breathing. Care was taken not to compromise placental circulation until the lamb was sacrificed by clamping the cord.

Gestational ages were estimated by the data of Barcroft (5). First the gestational age was estimated from the weight, then from the crown-rump length, and the average of the two was the assigned gestational age. The lambs ranged in fetal age from 60 to 140 days and were divided into three groups: immature (60 to 120 days), transitional (120 to 130 days), and near term (130 days to term).

The heart and lungs were carefully dissected from the chest in a block, and the right lung was used for pressure-volume studies. In sheep the right upper lobe bronchus arises directly from the trachea and thus permits individual pressure-volume studies on both upper and lower portions of the right lung. Nineteen of the 60 available lung specimens were technically satisfactory for pressure-volume studies. Inflation and deflation with air were carried out in increments of $5 \mathrm{~cm}$ of water, allowing 2 minutes at each pressure for volume equilibration. The deflation curves were plotted with volumes expressed as a per cent of that volume obtained at $40 \mathrm{~cm}$ water deflation pressure, since all lungs shared this pressure (6).

Tissue samples of $2.5 \mathrm{~g}$ were finely minced with scissors in $50 \mathrm{ml} 0.9 \%$ saline and agitated with a magnetic stirrer for 15 minutes. The resultant saline extract was filtered through lint-free gauze onto the Teflon trough of a modified Wilhelmy surface tension balance (7). The extract was aged for 30 minutes and then cycled for 3 hours at room temperature and in room air. Each cycle of 10 minutes' duration compressed the surface to $20 \%$ of the expanded area. The minimal surface tension was defined as the lowest value noted after 3 hours of cycling.

Representative samples of lung tissue were prepared for microscopy by fixation in $5 \%$ glutaraldehyde in Hank's balanced salt solution, $\mathrm{pH} 7.4$, for 1 hour and then in $1 \%$ osmium tetroxide in Hank's balanced salt solution, $\mathrm{pH} 7.4$, for 1 hour. The tissue was embedded in Epon 812, and 1- $\mu$ sections were stained with toluidine blue for light microscopy. All tissues were sectioned with a Sorvall MT2 microtome. Electron micrographs were prepared on uncoated grids for an RCA 3G electron microscope. ${ }^{1}$

Tissue samples contiguous to those used for surface tension measurements were analyzed for dry weight, DNA, and phospholipid content. The specimens, obtained from both upper and lower lobes within a few minutes after the animal was sacrificed, were weighed on preweighed papers to the nearest $0.1 \mathrm{mg}$ and placed in a constant temperature oven at $65^{\circ} \mathrm{C}$. After 3 days they

1 The light and electron microscopic studies were performed by Dr. R. Bergman of the Department of Anatomy. were weighed daily until two consecutive weights did not differ by more than $0.5 \mathrm{mg}$. The per cent dry weight was calculated, using the lowest weight noted.

Duplicate samples of lung for deoxyribonucleic acid determinations were taken from upper and lower lobes adjacent to those used for the dry weight analyses. These samples were also weighed to the nearest $0.1 \mathrm{mg}$. The tissue was homogenized in a Potter-Elvehjem glasson-glass tissue grinder and the deoxyribose nucleic acid content determined by the colorimetric method of Schneider (8), with a direct conversion from the optical density value obtained to milligrams DNA per gram wet weight. The average value for the two samples was then calculated.

Lung tissue for lipid analysis, adjacent to that previously sampled, was homogenized at room temperature in $5.0 \mathrm{ml}$ methanol in the tissue grinder; $10 \mathrm{ml}$ of chloroform was added and the resultant chloroform-methanol (2:1) solvent was used to extract the lipids according to the method of Folch and associates (9). The tissue suspension was filtered through Whatman 1 filter paper into $100-\mathrm{ml}$ volumetric cylinders and the trapped tissue washed with an additional $35 \mathrm{ml}$ chloroform-methanol $(2: 1)$. Further extraction of selected samples of lung tissue for periods up to twenty-four hours revealed an initial extraction of at least $95 \%$ by this method. The chloroform-methanol extract was washed with a portion $(0.2 \mathrm{ml}$ wash $/ 1 \mathrm{ml}$ extract) of $0.74 \%$ potassium chloride, establishing a two phase system. The upper methanolwater phase was discarded, and the lower chloroform phase was expanded to $50 \mathrm{ml}$ with chloroform-methanol $2: 1$. The fluff formed at the interphase of this system readily dissolved upon addition of chloroform-methanol. All tissue samples and lipid extracts were stored at $-10^{\circ}$ $C$ until analyzed, and most determinations were done within 1 week.

Samples of the washed chloroform-methanol extract were taken to dryness under nitrogen and analyzed for phosphorus content according to the colorimetric method of Bartlett (10). Duplicate analyses of lipid extracts that differed by less than $10 \%$ were averaged. The average lipid phosphorus content per gram lung tissue was multiplied by a factor of 25 to calculate the phospholipid content (11).

Paired samples of the chloroform-methanol extract were further analyzed by thin layer chromatography to determine the per cent composition of each constituent phospholipid. Glass plates were prepared according to the method of Skipski, Peterson, Sanders, and Barclay with silica $\mathrm{H}$, made slightly basic with $0.01 \mathrm{M}$ sodium acetate (12). One-ml samples of chloroform-methanol extract $(2: 1)$ were dried and spotted on $3.0-\mathrm{cm}$ lanes with commercially available phospholipid standards. Paired samples on thin layer plates were developed in a solvent system of chloroform: methanol: acetic acid: water $100: 60: 16: 10$ at room temperature. Seven areas were identified after exposure to iodine vapor: the origin, lysophosphatidyl choline, sphingomyelin, phosphatidyl choline, phosphatidyl serine, phosphatidyl ethanolamine, and the solvent front. No attempt was made to identify 
other compounds. Each spot was marked and scraped into a separate tube for phosphorus determination as described by Parker and Peterson (13).

The phosphatidyl choline was further studied for its fatty acid composition. Phospholipids for fatty acid analysis were identified with rhodamine $G$ rather than iodine vapor. The methylation of lung phosphatidyl choline fatty acids was performed in a $3 \%$ solution of concentrated sulfuric acid in methanol under nitrogen overnight at $65^{\circ} \mathrm{C}$ without eluting the phospholipid from the silica. Subsequently the methyl esters of the fatty acids were extracted three times with petroleum ether, dried under nitrogen, and stored at $-10^{\circ} \mathrm{C}$.

Lung phosphatidyl choline was further analyzed for fatty acid composition at the beta position. The phosphatidyl choline was eluted from silica with chloroformmethanol $2: 1$ and taken to dryness under nitrogen. Crotalus adamanteus lyophilized venom, $2.0 \mathrm{mg}$ in $0.2 \mathrm{ml}$ Tris buffer with calcium, $\mathrm{pH} 7.43$ at $23^{\circ} \mathrm{C}$, was added to each sample with $5.0 \mathrm{ml}$ diethyl ether. The reaction was allowed to proceed 15 minutes at room temperature. The mixture was agitated and the diethyl ether supernatant removed and dried under nitrogen. After snake venom hydrolysis, lysophosphatidyl choline was the only phospholipid evident on thin layer chromatography. It was assumed that the free fatty acids were derived from the beta position $(14,15)$. The free fatty acids from the

2 Ross Allen Reptile Institute, Silver Springs, Fla. beta position in the solvent front were methylated, extracted, dried, and stored as described above.

Fatty acid methyl esters were analyzed in a hydrogen flame gas-liquid chromatograph with a diethylene glycol succinate column. Commercial fatty acid methyl esters and corn oil methyl esters were used to identify the constituent fatty acids. Comparative quantification was carried out by triangulation of the fatty acid peaks. The total percent of saturated fatty acids $(14: 0,16: 0$, and 18:0) was determined for each sample for the whole and beta positions and the alpha position calculated from these values. Preliminary determinations of fatty acid patterns from lung phosphatidyl choline indicated that myristic, palmitic, palmitoleic, stearic, oleic, and linoleic acids were present in almost all samples and comprised 95\% of the constituent fatty acids. Arachidonic acid $(20: 4)$, found to constitute less than $5 \%$ of the total, was not included in the calculation.

The calculation of either the maximal or minimal possible concentration of disaturated phosphatidyl choline can be made from these data. The values shown in Table $I$ as the minimal concentration of disaturated phosphatidyl choline that must have been present are based on the reasoning that a molecule could have one saturated and one unsaturated fatty acid at either the alpha or beta position, or have two saturated or two unsaturated fatty acids. If the concentration of unsaturated fatty acids at either position is subtracted from the concentration of saturated fatty acids at the other position,

TABLE I

Per cent saturated fatty acids from lung phosphatidyl choline

\begin{tabular}{|c|c|c|c|c|c|}
\hline & $\underset{(13)^{*}}{\operatorname{Immature}}$ & $\begin{array}{c}\text { Transitional } \\
(7)\end{array}$ & $\begin{array}{c}\text { Near term } \\
\text { (5) }\end{array}$ & $\begin{array}{c}\text { Newborn } \\
\text { (2) }\end{array}$ & $\begin{array}{c}\text { Adult } \\
\text { whole } \\
\text { lung } \\
(5)\end{array}$ \\
\hline $\begin{array}{l}\text { Upper lobes } \\
\text { Wholet }\end{array}$ & $\begin{array}{l}56.2 \\
\pm 0.65 \ddagger\end{array}$ & $\begin{array}{c}61.4 \\
\pm 1.69\end{array}$ & $\begin{array}{c}65.7 \\
\pm 3.45\end{array}$ & 70.8 & $\begin{array}{l}67.3 \\
\pm 2.41\end{array}$ \\
\hline Beta $\dagger$ & $\begin{array}{l}50.3 \\
\pm 1.88\end{array}$ & $\begin{array}{l}59.0 \\
\pm 5.35\end{array}$ & $\begin{array}{c}63.2 \\
\pm 4.98\end{array}$ & 69.6 & $\begin{array}{c}54.4 \\
\pm 5.39\end{array}$ \\
\hline Alpha $†$ & $\begin{array}{c}62.4 \\
\pm 2.63\end{array}$ & $\begin{array}{l}63.8 \\
\pm 4.75\end{array}$ & $\begin{array}{c}67.9 \\
\pm 5.21\end{array}$ & 72.0 & $\begin{array}{c}79.0 \\
\pm 10.49\end{array}$ \\
\hline Minimal disaturates§ & $\begin{array}{r}12.7 \\
\pm 1.4\end{array}$ & $\begin{array}{r}22.8 \\
\pm 3.4\end{array}$ & $\begin{array}{r}31.0 \\
\pm 6.5\end{array}$ & 41.5 & 33.4 \\
\hline $\begin{array}{l}\text { Lower lobes } \\
\text { Whole }\end{array}$ & $\begin{array}{c}56.1 \\
\pm 0.41\end{array}$ & $\begin{array}{c}59.3 \\
\pm 1.79\end{array}$ & $\begin{array}{c}65.6 \\
\pm 2.48\end{array}$ & 66.1 & \\
\hline Beta & $\begin{array}{c}48.4 \\
\pm 1.24\end{array}$ & $\begin{array}{c}57.1 \\
\pm 2.69\end{array}$ & $\begin{array}{l}56.4 \\
\pm 4.48\end{array}$ & 67.9 & \\
\hline Alpha & $\begin{array}{l}64.1 \\
\pm 1.18\end{array}$ & $\begin{array}{l}61.5 \\
\pm 3.85\end{array}$ & $\begin{array}{c}74.8 \\
\pm 2.43\end{array}$ & 64.2 & \\
\hline Minimal disaturates & $\begin{array}{r}12.5 \\
\pm 0.3\end{array}$ & $\begin{array}{r}18.7 \\
\pm 3.6\end{array}$ & $\begin{array}{r}31.1 \\
\pm 4.9\end{array}$ & 32.1 & \\
\hline
\end{tabular}

* The numbers in parentheses indicate number of analyses.

† Whole and beta position saturated fatty acids were measured, and the alpha position was calculated.

$\ddagger \pm 1 \mathrm{SE}$.

$\S$ Minimal disaturates $=$ minimal percentage of saturated fatty acids at either alpha or beta position, which dictates concentration of $\alpha$-saturated and $\beta$-saturated phosphatidyl choline. 
the remaining concentration of saturated fatty acids must represent the minimal concentration of disaturated molecules. This value was multiplied by the concentration of total phospholipid and the per cent concentration of phosphatidyl choline to give the smallest possible amount of disaturated phosphatidyl choline that could be present (Figure 11).

\section{Results}

Gestational ages, estimated from weights and crown-rump lengths with the data of Barcroft (5), have the greatest degree of scatter beyond 130 days. This observation is pertinent to Figures $1,4,10$, and 11 in which gestational age is used as an abscissa. Since the 135 - to 140 -day animals were singletons, and Barcroft's measurements were on twins, our animals may be less mature than indicated.

Lung water content. Figure 1 illustrates the changes in per cent dry weight during gestation. The very immature lung at 60 days had a high water content of $94 \%$ ( $6 \%$ dry weight). With maturation the per cent dry weight increased to $13 \%$ at 100 days and maintained this level until approximately 125 days, at which time dry weight was again noted to decrease. The per cent dry weight continued to decrease toward 135 to 140 days, reaching approximately 6 to $8 \%$, and then rapidly increased to adult values of about $20 \%$ at 2 days of age.

Pressure-volume relationships. Figure 2 represents deflation pressure-volume characteristics for the immature, the transitional, and the mature

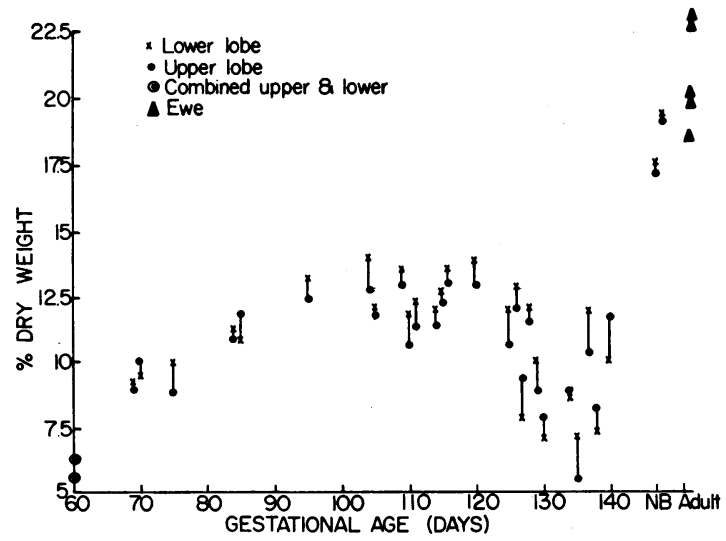

Fig. 1. Change in PER CENT DRY Weight IN FETAL (26), NEWBORN (2), AND ADULT (5) LUNGS. Vertical lines designate upper and lower lobes from the same animal.

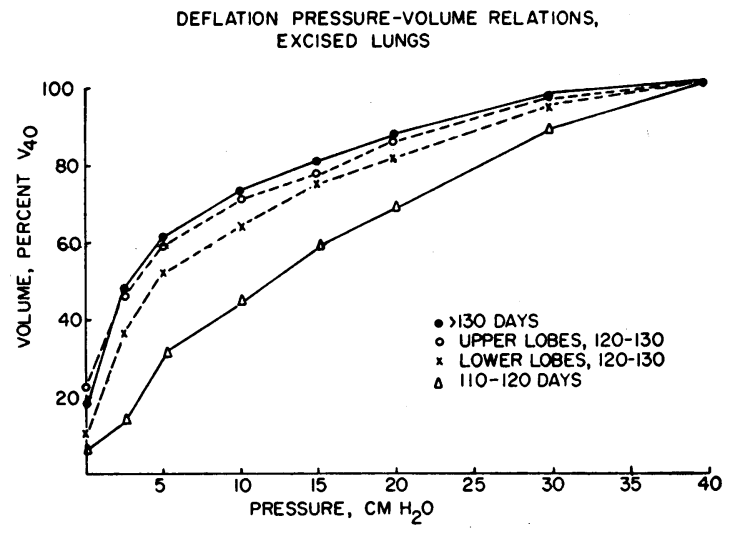

Fig. 2. Deflation PRESSURE-VOLUME CURVES FOR the THREE GROUPS OF FETAL LUNGS, WITH VOLUME EXPRESSED

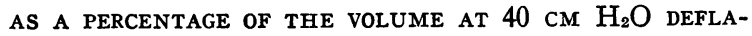
TION PRESSURE. The curves of the mature, upper lobe transitional, lower lobe transitional, and immature groups are the means of $9,6,6$, and 6 lobes, respectively.

groups. Both upper and lower lobe deflation curves are presented for lungs from the transitional group. The observed differences in deflation are significant $(p<0.05)$ at all distending pressures below $15 \mathrm{~cm} \mathrm{H}_{2} \mathrm{O}$, when the immature lungs are compared with all others. When lower lobes are compared with upper lobes, the differences are significant only at $2.5 \mathrm{~cm} \mathrm{H}_{2} \mathrm{O}(\mathrm{p}<0.05)$. No significant differences are present between upper transitional lobes and mature lungs. Since there were no differences between upper and lower lobe determinations within the immature and the mature groups, these studies are grouped together. In the lambs under 120 days the deflation pattern is characterized by minimal air trapping and complete collapse at low transpulmonary pressures. In the transitional animals a change is noted with the lower lobe retaining more air than the immature lung but considerably less than the upper portion (Figure 3). The upper lobe of this transitional group has deflation characteristics nearly identical to the mature lungs. Such upper-lower lobe pressure-volume differences were present in three of four lungs analyzed.

Surface tension values. The development of minimal surface tension values below 15 dynes per $\mathrm{cm}$ occurred between 125 and 130 days, considerably before term (Figure 4). During this transitional period the upper lobe minimal surface tension values were below 15 dynes per $\mathrm{cm}$, whereas the lower lobe values remained higher. 

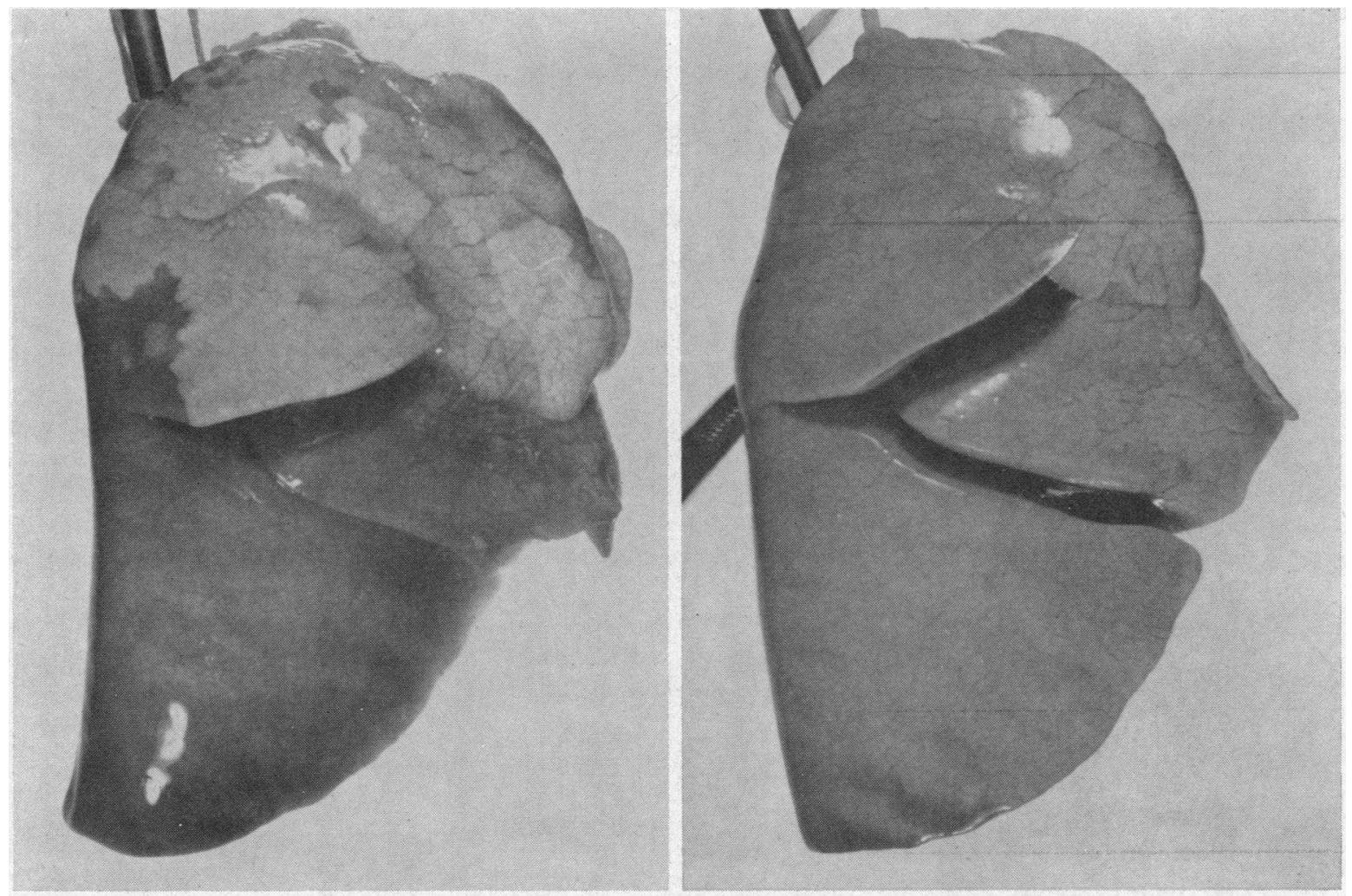

Fig. 3. Fully inflated transitional LaMb LUNG (RIGHT LUNG) With NO DEteCtable UPPER-LOBE DIfFERENCES, AND AFTER DEFLATION TO ATMOSPHERIC PRESSURE (LEFT) TO SHOW STABILITY OF THE UPPER LOBE.

Upper-lower lobe differences persisted after 130 days, although with one exception, all values were under 15 dynes per $\mathrm{cm}$.

Morphology. Figures 5 to 9 show light and electron photomicrographs of representative lung

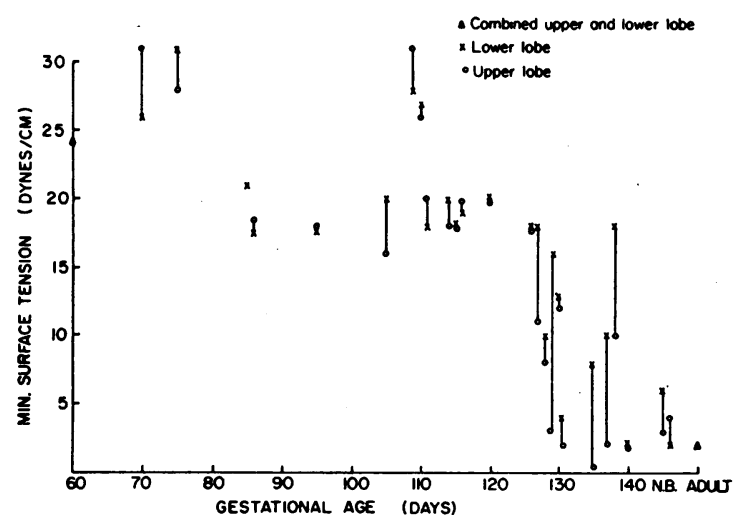

Fig. 4. Comparison OF MINIMAL SURFACE TENSION (DYNES PER CM) OF FETAL, NEWBORN, AND ADULT LUNGS. The adult point represents the mean of 5 values. Vertical lines connect upper and lower lobes from the same animal. tissue from immature, pretransitional, and transitional fetal lambs. One- $\mu$ sections illustrate the change from the glandular lung characteristic of the 85-day lamb (Figure 5) to the pretransitional animal at 115 days (Figure 6). The latter shows

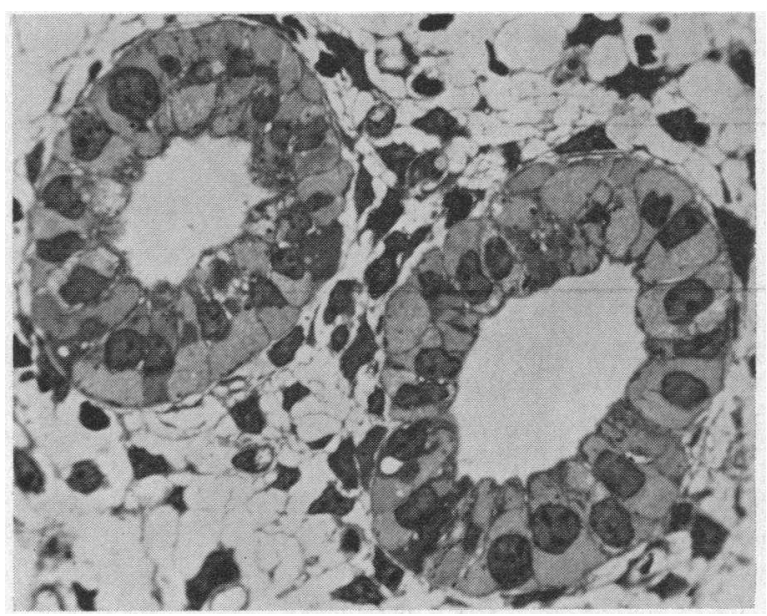

Fig. 5. Glandular Potential airspace of 85-day LAMB. $\times 1,000$ 


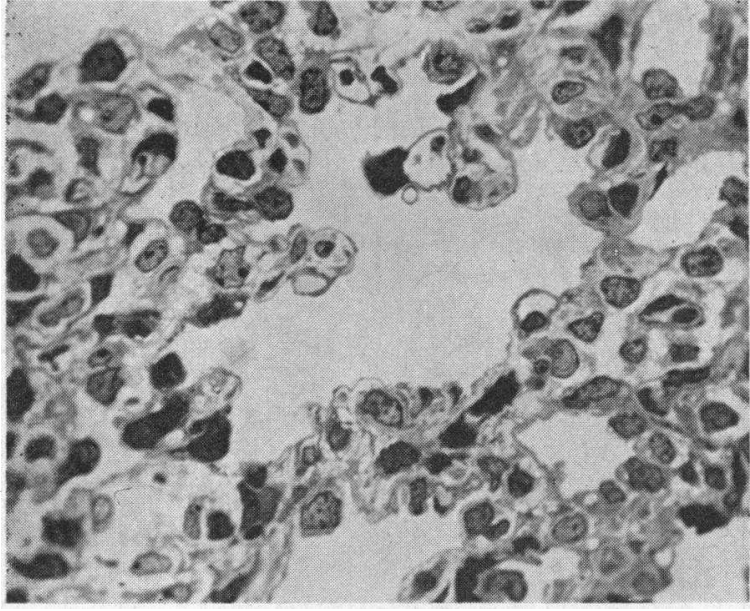

Fig. 6. Pretransitional Lamb of 115 Days Showing attenUation of ALVEOLAR EPITHELiUm. $\times 1,000$.

attenuation of alveolar epithelial cells. Figures 7 and 8 show upper and lower lobes, respectively, of a transitional lung at 128 days gestational age in which the upper lobe appears to have a larger number of inclusion-containing alveolar cells than the lower lobe. In the other transitional animal studied, sections of both upper and lower lobes showed only rare osmiophilic inclusion bodies although there were biochemical differences.

Figure 9 is an electron photomicrograph of an upper lobe of the 128-day transitional animal whose light microscopy is shown in Figure 7. The representative large alveolar cell has multiple

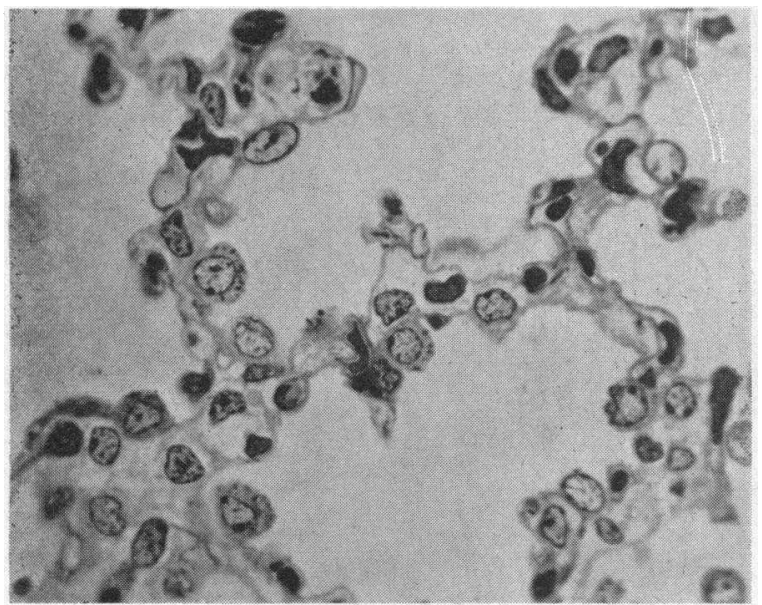

FIG. 7. UPPER LOBE OF TRANSITIONAL LAMB OF 128 DAYS SHOWING OSMIOPHILIC INCLUSION BODIES IN THE CYTOPLASM OF THE LARGE ALVEOLAR CELLS THAT PROTRUDES INTO THE ALVEOLUS. $\times 1,000$.

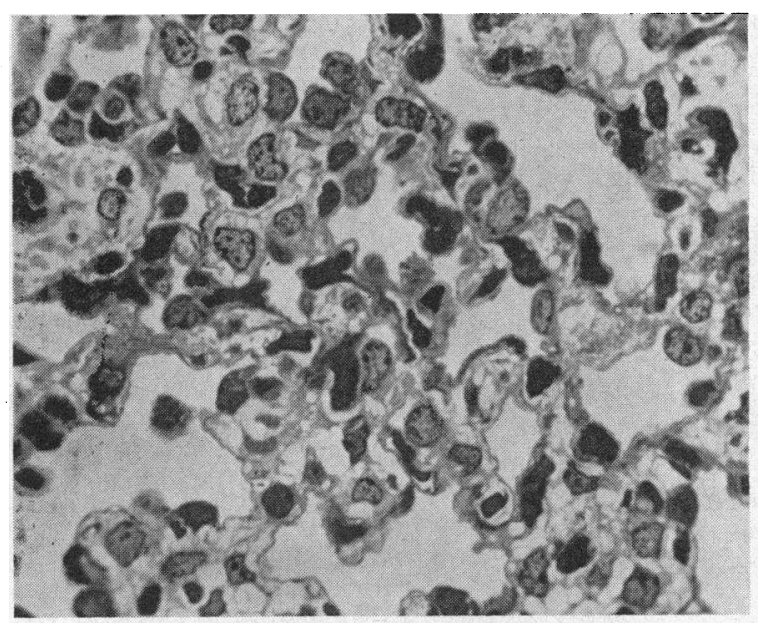

Fig. 8. LOWER LOBE OF TRANSITIONAL LAMB OF 128 DAYS SHOWING LESS ATTENUATION OF ALVEOLAR EPITHELIUM AND FEWER LARGE ALVEOLAR CELLS THAN UPPER LOBE. $\times 1,000$.

osmiophilic inclusion bodies, which appear as dark cytoplasmic granules under light micoscopy.

Lipid studies. The phospholipid content of the lungs, expressed as milligrams of phospholipid per milligram of DNA, remained stable at an average of $1.51 \mathrm{mg}$ phospholipid per mg DNA from early fetal life until about 120 days of age (Figure 10,

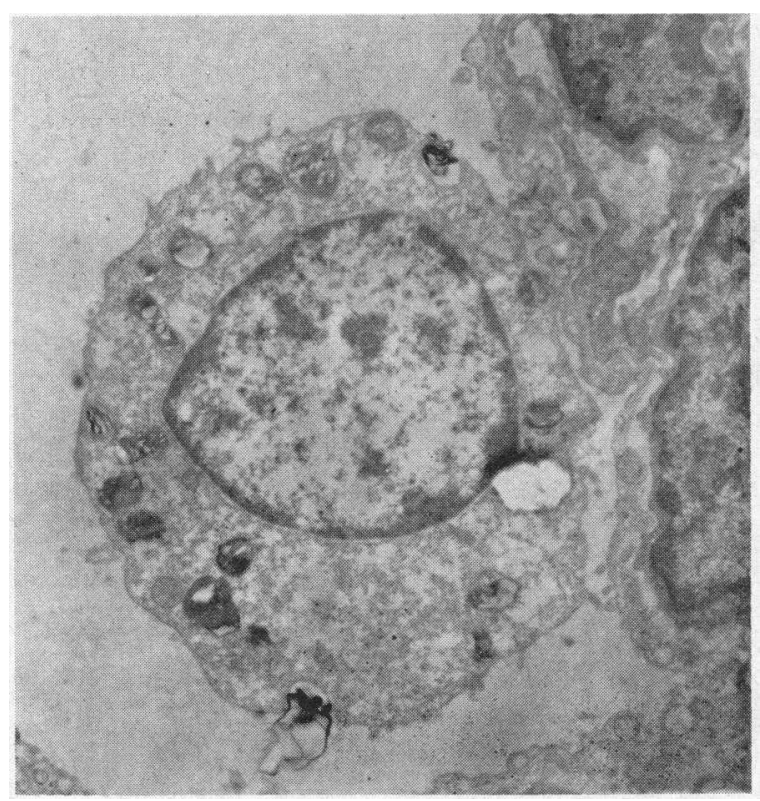

Fig. 9. Representative LARge Alveolar CELl FROM UPPER LOBE OF THE TRANSITIONAL ANIMAL SHOWN IN FigURE 7. $\times 2,500$. The cytoplasmic granules observed by light microscopy are the osmiophilic inclusions. 
TABLE II

Lamb lung phospholipids during gestation*

\begin{tabular}{|c|c|c|c|c|c|c|c|c|c|}
\hline \multirow[b]{2}{*}{ Gestational age: } & \multicolumn{2}{|c|}{$\begin{array}{l}\text { Immature } \\
60-170 \text { days }\end{array}$} & \multicolumn{2}{|c|}{$\begin{array}{l}\text { Transitional } \\
120-130 \text { days }\end{array}$} & \multicolumn{2}{|c|}{$\begin{array}{l}\text { Near term } \\
130 \text { days-term }\end{array}$} & \multicolumn{2}{|c|}{ Newborn } & \multirow[b]{2}{*}{ Adults } \\
\hline & Upper & Lower & Upper & Lower & Upper & Lower & Upper & Lower & \\
\hline mg PL/g wet wt & $\begin{aligned} & 8.6(15) \dagger \\
\pm & 0.5 \ddagger\end{aligned}$ & $\begin{array}{l}9.4(14) \\
\pm 0.6\end{array}$ & $\begin{array}{l}10.6(7) \\
\pm 0.7\end{array}$ & $\begin{array}{l}10.9(7) \\
\pm 0.8\end{array}$ & $\begin{array}{l}11.7(5) \\
\pm 1.4\end{array}$ & $\begin{array}{l}11.4(5) \\
\pm 1.0\end{array}$ & $32.2(2)$ & $33.6(2)$ & $\begin{array}{l}19.1(5) \\
\pm 2.3\end{array}$ \\
\hline $\mathrm{mg}$ PL/g dry wt & $\begin{array}{l}80.9(15) \\
\pm 3.5\end{array}$ & $\begin{array}{l}87.0(14) \\
\pm 4.9\end{array}$ & $\begin{array}{l}102.5(7) \\
\pm 4.7\end{array}$ & $\begin{array}{l}102.4(7) \\
\pm 5.3\end{array}$ & $\begin{array}{l}139.1(5) \\
\pm 23.3\end{array}$ & $\begin{array}{l}129.3(5) \\
\pm 13.2\end{array}$ & $176.8(2)$ & $182.8(2)$ & $\begin{array}{l}107.6(3) \\
\pm 7.8\end{array}$ \\
\hline $\mathrm{mg}$ DNA/g wet wt & $\begin{aligned} & 5.9(10) \\
\pm & 0.4\end{aligned}$ & $\begin{array}{l}\quad 6.2(12) \\
\pm 0.4\end{array}$ & $\begin{aligned} & 5.2(6) \\
\pm & 0.5\end{aligned}$ & $\begin{aligned} & 6.2(7) \\
\pm & 0.6\end{aligned}$ & $\begin{aligned} & 5.2(5) \\
\pm & 0.8\end{aligned}$ & $\begin{aligned} & 5.6(5) \\
\pm & 0.5\end{aligned}$ & $7.6(2)$ & $8.3(2)$ & $\begin{aligned} & 5.1(3) \\
\pm & 0.3\end{aligned}$ \\
\hline $\mathrm{mg} \mathrm{PL} / \mathrm{mg} \mathrm{DNA}$ & $\begin{aligned} & 1.5(10) \\
\pm & 0.06\end{aligned}$ & $\begin{array}{l}1.6(11) \\
\pm 0.09\end{array}$ & $\begin{array}{l}2.3(5) \\
\pm 0.2\end{array}$ & $\begin{aligned} & 1.8(6) \\
\pm & 0.07\end{aligned}$ & $\begin{aligned} & 2.4(5) \\
\pm & 0.2\end{aligned}$ & $\begin{aligned} & 2.0(5) \\
\pm & 0.1\end{aligned}$ & $4.2(2)$ & $4.0(2)$ & $\begin{array}{l}3.3(3) \\
\pm 0.5\end{array}$ \\
\hline
\end{tabular}

* PL = phospholipid; DNA = deoxyribose nucleic acid; upper and lower $=$ upper and lower lobes of the lung. $\dagger$ The numbers in parentheses indicate number of specimens in each group.

$\ddagger \pm 1 \mathrm{SE}$.

Table II). During the transitional period (120 to 130 days) the phospholipid content was higher in the upper lobes than in the lower lobes. In the newborn lambs, phospholipid values for both upper and lower lobes were similar and close to the values for the ewe lung.

Phosphatidyl choline was the largest component of the five constituent phospholipids measured and ranged from $43 \%$ in the immature to $59 \%$ in the newborn. No significant upper-lower lobe differences in the per cent of phosphatidyl choline were found. Since phosphatidyl choline was the only phospholipid that increased during gestation, the fatty acids of the whole molecule and the beta position were analyzed (Table I).

The per cent saturation of fatty acids of the whole molecule showed a significant increase from the immature to the transitional lambs, and a simi-

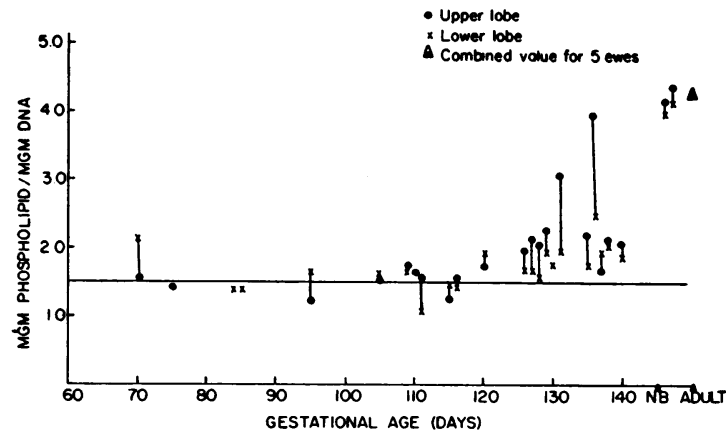

Fig. 10. COMPARISON OF MILLIGRAMS PHOSPHOLIPID PER MILLIGRAM DNA AMONG FETAL, NEWBORN, AND ADULT LUNGS. The horizontal line at $1.5 \mathrm{mg}$ phospholipid per mg DNA represents the mean value for all lobes before 120 days gestation. lar increase from the transitional to the near term animals, reflecting primarily the change in the beta position. Upper and lower lobe saturated fatty acid differences were not statistically significant. The minimal concentration of saturated fatty acids available to form disaturated molecules is represented for both upper and lower lobes and shows a 2.5-fold increase from immaturity to near term. The numbers of newborn and adults were too few to permit statistical comparison.

The calculated minimal concentration of disaturated phosphatidyl choline per milligram DNA is plotted against gestational age (Figure 11).

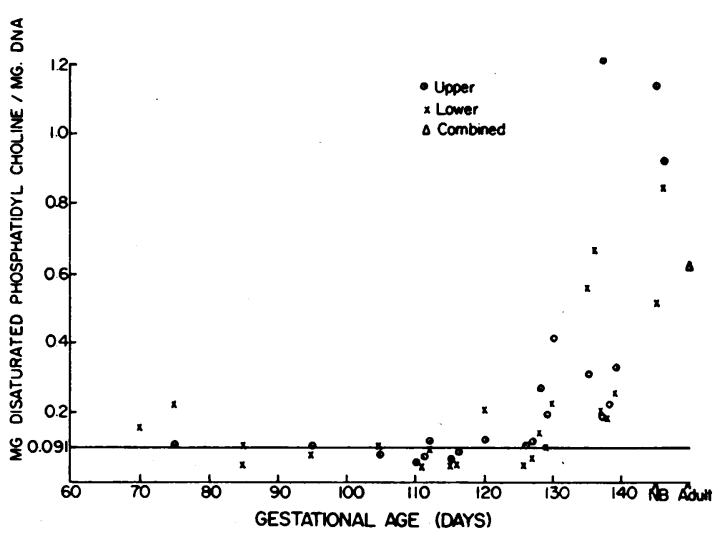

Fig. 11. Comparison of milligrams disaturated PHOSPHATIDYL CHOLINE (LECITHIN) PER MILLIGRAM DNA OF FETAL, NEWBORN, AND ADULT LUNGS. The adult value represents the mean of 2 determinations, and the horizontal line at $0.091 \mathrm{mg}$ disaturated phosphatidyl choline per mg DNA represents the mean of all values before 120 days gestation. The minimal concentration of disaturated phosphatidyl choline is plotted. 


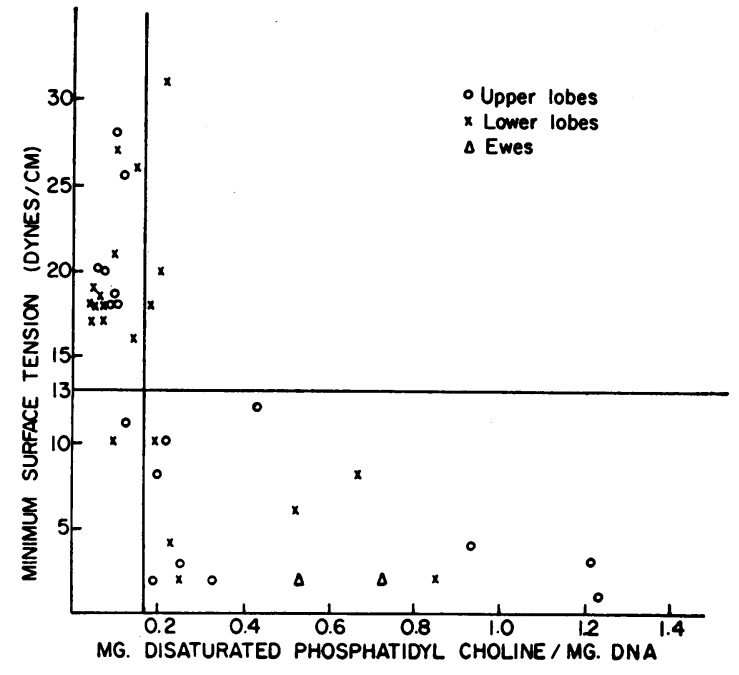

Fig. 12. Relationship BETWEen Minimal SURFACE TENSION AND MILLIGRAMS DISATURATED LECITHIN PER MILLIGRAM DNA (MINIMAL CONCENTRATION).

Before 120 days, the mean value was $0.091 \mathrm{mg}$ disaturated phosphatidyl choline per mg DNA. During the transitional phase (120 to 130 days) the mean upper lobe values were higher than the mean lower lobe values, and this relationship was maintained until term. The concentration of disaturated phosphatidyl choline increased to approximately $1.0 \mathrm{mg}$ per $\mathrm{mg}$ DNA in the newborn, an increase of about 10 -fold from the immature level.

Results of surface tension measurements are plotted against values of disaturated phosphatidyl choline in Figure 12. Seventeen of 20 specimens that contained a concentration of disaturated phosphatidyl choline greater than $0.170 \mathrm{mg}$ per $\mathrm{mg}$ DNA had minimal surface tension values below 13 dynes (chi square, $\mathrm{p}<0.001$ ).

\section{Discussion}

The measurements on the upper and lower lobes of lambs' lungs of different gestational ages have permitted morphological, physiological, and biochemical comparisons. It is evident that with the structural maturation of the lung there is concurrent biochemical maturation. In this study using multiple measurements on the same lungs, the principal observation was the dramatic maturational change in the functional and biochemical indexes of the 120 - to 130-day lamb lung, with the upper lobe maturation preceding the lower lobe. This change appears necessary for the development of the immature lung to the mature postnatal organ of gas exchange. Although it is not possible to assign cause and effect in these descriptive studies, the coincidence of the events supports the possibility that changes in the pressure-volume characteristics are related to the presence of the pulmonary surfactant, and it, in turn, has as an important constituent, disaturated phosphatidyl choline.

Lung water content. One of the well-known characteristics of developing tissues is a tendency to decrease their water content during maturation. The lung shares in this trend until about 100 days gestational age. Before that time it is a glandular organ with very little potential airspace. After 100 days, lung water content stabilizes until about 120 days, despite the increase in organ weight. Thereafter, unlike all other organs, the water content actually increases by about $5 \%$, coincident with the increase in the size and numbers of airways, which are fluid filled and presumably account for the increase in water $(16,17)$. Fauré-Fremiet and Dragoiu were the first to note the change in water content although their data toward term are inconclusive (1). Our results differ from those of Orzalesi and co-workers (2) in the later time of increase in water content. The reasons for the difference are not clear.

The observation of a changing water content in the lung required that chemical determinations be expressed per gram dry weight or per milligram DNA. The constancy of $6.2 \mu \mu \mathrm{g}$ of DNA per nucleus in organs other than the liver has led other investigators to use this expression as an index of cell number (18). The constancy of the DNA content per gram dry weight in the lungs of this study indicated that either measurement could be used as a reference value. However, the scatter in the data was least when plotted per milligram DNA.

Pressure-volume and surface tension studies. The static-elastic properties of the excised lung inflated with air are markedly different from those seen in saline inflation; this difference has been interpreted as a measure of the contribution of surface forces (19). All of the lambs of less than 120 days were characterized by poor distensibility in the sense that they hold less air at 50 to $60 \mathrm{~cm}$ $\mathrm{H}_{2} \mathrm{O}$ pressure, and indeed distensibility tended 
to increase through gestation. Similar changes in distensibility with advancing gestation were previously reported by Born, Dawes, and Mott (20). When lung volume was expressed relative to the volume at $40 \mathrm{~cm} \mathrm{H}_{2} \mathrm{O}$, the deflation characteristics of the lamb lungs in this study fell into four groups. The lungs of less than 120 days held a smaller per cent of their total capacity at all deflation pressures than lungs of older animals, and the lungs were airless at atmospheric pressure. Upper lobes from the transitional animals were more stable, in that they held a greater per cent of total capacity at each pressure than the lower lobes from the same animals, as previously noted by Howatt and associates (4). All lobes of the near term animals, like the upper lobes of the transitional lambs, were capable of holding more than $60 \%$ of their lung capacity at $5 \mathrm{~cm} \mathrm{H}_{2} \mathrm{O}$ pressure, and they had a finite air volume at atmospheric pressure characteristic of adult animals. The minimal surface tension, as measured on the Wilhelmy balance, correlated with stable pressure-volume relationships.

Morphological changes. The weight of evidence supports the concept that the osmiophilic inclusion body of the large alveolar cell may be a storage organelle for pulmonary surfactant. The inclusions, originally thought to be transformed mitochondria $(21,22)$, differ from mitochondria histochemically $(23,24)$. Kikkawa, Motoyama, and Cook have shown a striking change in the large alveolar cell of the fetal lung, noting the appearance of osmiophilic inclusion bodies around 120 days and their continued increase until 135 days (3). Recent studies in other species relate the presence of the inclusions to the ability to detect the surfactant on the surface film balance $(21,25$, 26).

In general, the histological findings in this study support the observations of Kikkawa and co-workers showing a progressive increase in osmiophilic inclusions from approximately 120 to 135 days gestational age. Although quantitation of the inclusions was not undertaken in our study, the inclusions were seen in some lower lobes in the absence of detectable surfactant. The presence of osmiophilic inclusions in the absence of surfactant suggests a more complex relationship than previously thought.

Lipid studies. It was in the light of the morpho- logical changes, and differences in distensibility and deflation characteristics, largely known from previous studies, that lipid analyses were undertaken to see whether biochemical changes would correlate with functional measurements in the same animals. A likely chemical change associated with the appearance of surfactant is the lipid concentration shown in the lamb to increase abruptly at 85 days and progress to a threefold increase by term (1). In the rat lung, too, the phospholipid content increases twofold between early fetal life and term (27).

The changing phospholipid content correlated well with pressure-volume and surface tension measurements. Since previous studies have indicated that a polar molecule with straight-chain fatty acids would be the best candidate to be the surfactant, and since the lung is known to contain large amounts of disaturated phosphatidyl choline, it seemed pertinent to direct studies in the lambs' lungs toward changes in saturated phospholipids (28-32). The increase in their concentration correlated in time with the presence of more mature mechanical properties of the lung. The differences in disaturated phosphatidyl choline with advancing gestation were more marked than those in upper and lower lobes. Upperlower lobe differences may have been obscured by the analysis of whole lung extracts rather than a specific surface-active fraction.

The presence of disaturated phosphatidyl choline in the mature lung and the increase noted in this compound during the gestation of the lamb suggest the maturation of pathways for the synthesis of this specific phospholipid. The observation in this study that the increase in phosphatidyl choline saturated fatty acids occurs primarily at the beta position further suggests that a specific beta acylase may constitute a portion of this synthetic process. This may account for qualitative changes, apart from quantitative increases, since not all of the noted increase in phospholipid content can be accounted for by increases in disaturated phosphatidyl choline.

The differences in composition of the newborn and the adult sheep lung are striking. The DNA content expressed per gram dry weight in the adult lung is approximately half that in the lamb. Since the phospholipid content of the adult lung is also approximately half that of the lamb, phospholipid 
concentrations expressed per milligram DNA are similar. Part of the decrease in DNA noted in the adult may reflect the decrease in number of large alveolar cells noted by Balis and Conen in the human (33). At least, it is evident that the mature lung is relatively less cellular than the fetal lung.

In the fetal lamb the accumulation of disaturated phosphatidyl choline continues after pressure-volume characteristics and surface tension measurements appear normal. If this compound is assumed to be an essential component of the surfactant, it appears that there is a significantly larger reserve in the newborn at term than in the premature or the adult. This is in keeping with the continued increase in number of osmiophilic inclusion bodies beyond 115 days in the lamb, which further indicates that they may represent a reservoir for the surfactant.

\section{Acknowledgments}

We would like to express our sincere appreciation to Drs. John Menkes, Arthur Karmen, and William R. Harlan, whose consultation, assistance, and provision of facilities were invaluable. The technical assistance of Mrs. Helen Scott was also greatly appreciated.

\section{References}

1. Fauré-Fremiet, E., and J. Dragoiu. Le dévelopement du poumon fotal chez le mouton. Arch. Anat. micr. Morph. exp. 1923, 19, 411.

2. Orzalesi, M. M., E. K. Motoyama, H. N. Jacobson, Y. Kikkawa, E. O. R. Reynolds, and C. D. Cook. The development of the lungs of lambs. Pediatrics $1965,35,373$.

3. Kikkawa, Y., E. K. Motoyama, and C. D. Cook. The ultrastructure of the lungs of lambs. The relation of osmiophilic inclusions and alveolar lining layer to fetal maturation and experimentally produced respiratory distress. Amer. J. Path. 1965, $47,877$.

4. Howatt, W. F., M. E. Avery, P. W. Humphreys, I. C. S. Normand, L. Reid, and L. B. Strang. Factors affecting pulmonary surface properties in the fotal lamb. Clin. Sci. 1965, 29, 239.

5. Barcroft, J. Researches on Prenatal Life. Springfield, Ill., Charles C Thomas, 1947, vol. 1, pp. 4251.

6. Johnson, J. W. C., S. Permutt, J. H. Sipple, and E. S. Salem. Effect of intra-alveolar fluid on pulmonary surface tension properties. J. appl. Physiol. 1964, 19, 769.

7. Clements, J. A. Surface phenomena in relation to pulmonary function. Physiologist 1962, 5, 11.
8. Schneider, W. C. Determination of nucleic acids in tissues by pentose analysis in Methods in Enzymology, S. P. Colowick and N. O. Kaplan, Eds. New York, Academic Press, 1957, vol. 3, p. 680.

9. Folch, J., I. Ascoli, M. Lees, J. A. Meath, and F. N. LeBaron. Preparation of lipide extracts from brain tissue. J. biol. Chem. 1951, 191, 833.

10. Bartlett, G. R. Phosphorus assay in column chromatography:' J. biol. Chem. 1959, 234, 466.

11. Ansell, G. B., and J. N. Hawthorne. Phospholipids, Chemistry, Metabolism and Function. Amsterdam, Elsevier, 1964, p. 50.

12. Skipski, V. P., R. F. Peterson, J. Sanders, and M. Barclay. Thin-layer chromatography of phospholipids using silica gel without calcium sulphate binder. J. Lipid Res. 1963, 4, 227.

13. Parker, F., and N. F. Peterson. Quantitative analysis of phospholipids and phospholipid fatty acids from silica gel thin-layer chromatograms. J. Lipid Res. 1965, 6, 455.

14. Robertson, A. F., and W. E. M. Lands. Positional specificities in phospholipid hydrolyses. Biochemistry 1962, 1, 804.

15. Blank, M. L., L. J. Nutter, and O. S. Privett. Determination of the structure of lecithins. Lipids 1966, 1, 132.

16. Avery, M. E., and C. D. Cook. Volume-pressure relationships of lungs and thorax in fetal, newborn, and adult goats. J. appl. Physiol. 1961, 16, 1034.

17. Adams, F. H., T. Fujiwara, and G. Rowshan. The nature and origin of the fluid in the fetal lamb lung. J. Pediat. 1963, 63, 881.

18. Enesco, M., and C. P. Leblond. Increase in cell number as a factor in the growth of the organs and tissues of the young male rat. J. Embryol. exp. Morph. 1962, 10, 530.

19. Radford, E. S. Handbook of Physiology: Respiration, 1st ed., W. O. Fenn and H. Rahn, Eds. Baltimore, Williams \& Wilkins, 1964, vol. 1, chap. 15.

20. Born, G. V. R., G. S. Dawes, and J. C. Mott. The viability of premature lambs. J. Physiol. (Lond.) 1955, 130, 191 .

21. Klaus, M., O. K. Reiss, W. H. Tooley, C. Piel, and J. A. Clements. Alveolar epithelial cell mitochondria as source of the surface-active lung lining. Science 1962, 137, 750.

22. Schulz, H. The submicroscopic anatomy and pathology of the lung. Berlin, Springer-Verlag, 1959, p. 64 .

23. Buckingham, S., W. F. McNary, Jr., and S. C. Sommers. Pulmonary alveolar cell inclusions: their development in the rat. Science 1964, 145, 1192.

24. Hatasa, K., and T. Nakamura. Electron microscopic observations of lung alveolar epithelial cell of normal young mice, with special reference to 
formation and secretion of osmiophilic lamellar bodies. Z. Zellforsch. 1965, 63, 266.

25. Buckingham, S., and M. E. Avery. Time of appearance of lung surfactant in the fotal mouse. Nature (Lond.) 1962, 193, 688.

26. Bensch, K., K. Schaefer, and M. E. Avery. Granular pneumocytes: electron microscopic evidence of their exocrinic function. Science 1964, 145, 1318.

27. Weinhold, P., and C. A. Villee. Phospholipid metabolism in the liver and lung of rats during development. Biochim. biophys. Acta (Amst.) 1965, 106, 540.

28. Abrams, M. E., and F. B. Taylor. Isolation and quantitative estimation of pulmonary surface ac- tive lipoprotein and its interaction with fibrinogen. Physiologist 1964, 7, 78.

29. Clutario, B. C., E. M. Scarpelli, and F. Taylor. Identification and source of surfactants in lung extracts. Fed. Proc. 1966, 25, 565.

30. Brown, E. S. Isolation and assay of dipalmityl lecithin in lung extracts. Amer. J. Physiol. 1964, 207, 402.

31. Felts, J. M. Biochemistry of the lung. Hlth Phys. 1964, 10, 973.

32. Gaines, G. J. Insoluble Monolayers at Liquid-Gas Interfaces, 1st ed. New York, Interscience, 1966, pp. 162-67.

33. Balis, J. U., and P. E. Conen. The role of alveolar inclusion bodies in the developing lung. Lab. Invest. 1964, 13, 1215. 